\title{
Pengaruh Jenis Humidifier (Spray Humidifier dan Pad Humidifier)Terhadap Produktivitas Unit Desalinasi Berbasis Pompa Kalor Dengan Menggunakan Proses Humidifikasi dan Dehumidifikasi
}

\author{
Indri Yaningsih, Tri Istanto \\ Jurusan Teknik Mesin Fakultas Teknik Universitas Sebelas Maret \\ Jl. Ir. Sutami no 36A Kentingan Surakarta 57126 \\ Telp/Fax: (0271) 632163 \\ E-mail: indriyaningsih@staff.uns.ac.id, triistanto@staff.uns.ac.id
}

\begin{abstract}
This research examined the effect of the use of spray humidifier and pad humidifier on the productivity of a desalination unit based heat pump with using humidification and dehumidification process. In spray humidifier there were 5 pieces of sprinklers for spraying sea water. In pad humidifier, sea water was distributed evenly over the top by means of sea water flowing through perforated pipes that have been placed on pad humidifier. Tested the effect of sea water volumetric flow rate, air velocity and sea water temperature which was fed to spray humidifier and pad humidifier on the fresh water production resulted from desalination unit.The research result showed that the production of fresh water increased with the increase in the sea water volumetric flow rate, air velocity, and sea water temperature, this applies to the use of spray humidifier or pad humidifier in the desalination unit.On testing of the effect of the sea water volumetric flow rate, air velocity, and sea water temperature, the performance of spray humidifier and pad humidifier was equal in the production of fresh water, when the ratio of sea water mass flow rate to air mass flow rate of 1.34, 1.3 and 1.3, respectively.
\end{abstract}

Keywords : dehumidification,desalination, humidification, pad humidifier, spray humidifier

\section{PENDAHULUAN}

Sejak dimulainya kehidupan di bumi, jumlah sumber air tawar yang ada di dunia dapat dikatakan hampir mendekati konstan. Namun dalam kurun waktu kurang dari 200 tahun, jumlah penduduk di dunia terus meningkat dengan cepat. Hal ini diikuti denganpeningkatan konsumsi air tawar didunia, yang meningkat dua kali lipat setiap 20 tahun melampaui dua kali laju pertumbuhan penduduk [1].

WHOmerekomendasikan batas minimal kebutuhan air adalah 15 - 20 liter/orang/hari, dimana jumlah ini hanya dapat digunakan untuk kebutuhan dasar seperti minum, persiapan makanan, kebersihan pribadi serta mencuci. Di Amerika Serikat konsumsi air rata-rata mencapai 400 liter per orang. Di beberapa negara di Afrika, konsumsi air tawar berada pada kisaran 20 liter per kapita per hari [2].

Sumber air yang hampir tidak akan habis adalah lautan. Kekurangan utamanya adalah kadar garamnya yang tinggi.Menurut WHO, batas kadar garam yang diijinkan dalam air adalah 500 parts per million (ppm), dan untuk kasus khusus mencapai 1.000 ppm. Sebagian besar air yang terdapat di dunia mempunyai kadar garam sampai 10.000 ppm, dan air laut secara normal mempunyai kadar garam dalam rentang $35.000-45.000 \mathrm{ppm}$ dalam bentuk total garam terlarut [3].

Air laut dapat dijadikan air tawardengan proses desalinasi. Desalinasisecara umum bertujuan untuk menghilangkan garam dari air yang mengandung larutan garam. Tujuan sistem desalinasi adalah untuk membersihkan dan memurnikan air laut atau air payau serta untuk mendapatkan air dengan total padatan terlarut dalam batas yang diijinkan yaitu 500 ppm atau kurang. Proses desalinasi ini melibatkan tiga aliran cairan, yaitu umpan berupa air garam (misalnya air laut), produk bersalinitas rendah, dan konsentrat bersalinitas tinggi.

Aplikasi pompa kalor (heat pump) dalam desalinasi telah mendapatkan perhatian dalam hal potensinya untuk mengurangi biaya. Dari analisis didapatkan bahwa unit desalinasi berbantuan pompa kalor dapat didesain sebagai unit mobile skala kecil untuk digunakan di daerah bencana atau skala besar untuk menghasilkan air minum untuk kota-kota dengan biaya yang kompetitif dibandingkan dengan teknologi reverse osmosis (RO) dan elektrodialisis. Potensi pompa kalor dalam teknologi desalinasi terletak pada kemampuannya untuk mengurangi konsumsi tenaga listrik yang mahal dan pemanfaatan kembali limbah panas.Salah satu perkembangan teknologi desalinasi adalah menggunakan pompa kalor dengan proses humidifikasi dan dehumidifikasi (HD). Proses HD terdiri dari tiga sub sistem, yaitu pemanas air atau udara, humidifier, dandehumidifier.

Penelitian tentang desalinasi berbasis pompa kalor dengan menggunakan proses HD telah banyak dilakukan. Slesarenko [4] melakukan analisis 
termodinamika yang menunjukkan bahwa pompa kalor adalah memungkinkan sebagai sumber energi panas untuk desalinasi air laut.Gao et al [5] meneliti unjuk kerja unit desalinasi berbasis pompa kalor dengan proses humidifikasi dan dehumidifikasi.Penelitian ini memanfaatkan panas kondensor untuk memanaskan udara dan temperatur permukaan evaporator yang rendah untuk menghasilkan air tawar serta pre-condenser untuk pemanasan awal air laut. Istanto et al [6] meneliti pengaruh temperatur masukan air laut dan temperatur udara terhadap unjuk kerja unit desalinasi berbasis pompa kalor dengan menggunakan proses humidifikasi dan dehumidifikasi. Yaningsih et al [79] meneliti pengaruh laju aliran massa udara, laju aliran massa air laut dan kecepatan putaran kompresor terhadap produktivitas unit desalinasi berbasis pompa kalor dengan menggunakan proses humidifikasi dan dehumidifikasi. Yanniotis, S., et al [10] melakukan penelitian tentang 2 jenis humidifier, yaitu tubular spray humidifier dan pad humidifier untuk proses desalinasi surya banyak tingkat.Hasil eksperimen berupa kapasitas penguapan dari kedua humidifier disajikan untuk kondisi operasi yang berbeda dari laju aliran udara dan air laut, temperatur udara dan air laut. Amara et al[11] melakukan penelitian secara eksperimen dan teoritis tentang pad humidifier yang digunakan dalam proses desalinasi surya banyak tingkat. Unit pad humidifier berisi rangkaian tiga kaset yang terbuat dari bahan selulosa bergelombang, dimana terdapat permukaan terbasahi. Amer et al [12]meneliti secara eksperimen dan teoritis unit desalinasi menggunakan proses humidifikasi dan dehumidifikasi. Hasil penelitian menunjukkan bahwa produktivitas air tawar dipengaruhi oleh jenis dan material humidifier. Penelitian ini membandingkan humidifier berbahan karung goni, berbahan kayu lapis, dan berbahan dasar dari PVC.

Unjuk kerja unit desalinasi dengan proses HD untuk meningkatkan produksi air tawar tergantung pada jenis humidifier,selain faktor-faktor lain seperti ; temperatur air laut dan udara masuk ke humidifier, laju aliran massa air laut dan udara. Penelitian ini akan menguji pengaruh penggunaan spray humidifier dan pad humidifierterhadap unjuk kerja unit desalinasi berbasis pompa kalor dengan menggunakan proses HD.

\section{METODE}

Skema dan gambar unit desalinasi berbasis pompa kalor dengan menggunakan proses HD pada penelitian ini berturt-turut dapat dilihat pada gambar 1 dan 2. Pada dasarnya unit desalinasi ini terdiri dari 3 bagian. Bagian pertama adalah pemanas air laut dan pemanas udara (kondensor), bagian kedua adalah komponen proses HD meliputi humidifier dan dehumidifier (evaporator), dan bagian ketiga adalah komponen pompa kalor dimana terdiri dari kompresor, kondensor, katup ekspansi (expansion valve) dan evaporator.

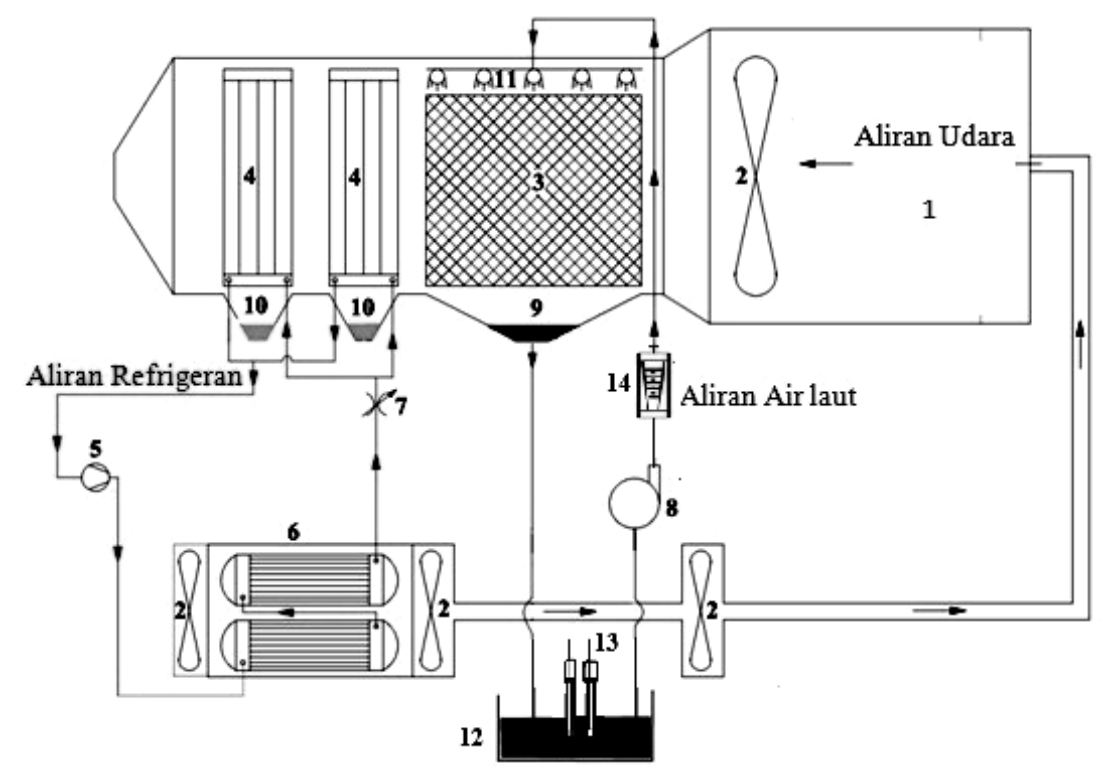

Gambar 1. Skema unit desalinasi berbasis pompa kalor dengan menggunakan proses humidifikasidandehumidifikasi (1) saluaran udara masuk, (2) fan aksial, (3) humidifier, (4) evaporator (dehumidifier), (5) kompresor,(6) kondenser, (7) katup ekspansi, (8) pompa sentrifugal, (9) konsentrat air laut, (10) penampung air tawar, (11) sprinkler (12) air laut umpan (13) pemanas air laut (14) rotameter 


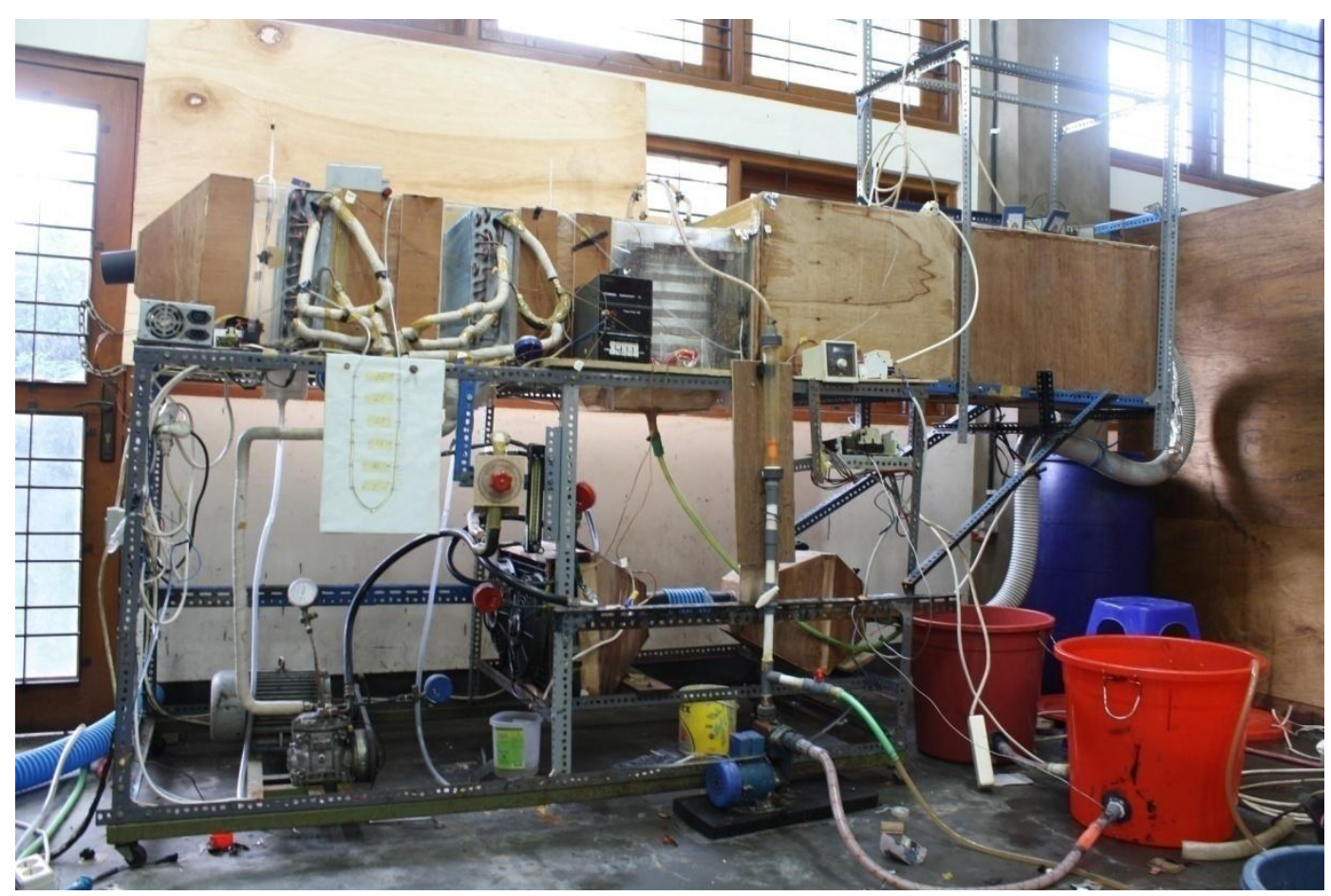

Gambar 2. Unit desalinasi berbasis pompa kalor dengan menggunakan proses humidifikasi dan dehumidifikasi

Prinsip kerja dari unit desalinasi berbasis pompa kalor dengan menggunakan proses HD ini adalah menggunakan udara panas untuk membawa uap air dari air laut, kemudian udara yang mengandung uap air ini diembunkan di evaporator dari sistem pompa kalor dan kemudian diperoleh air tawar (freshwater). Dalam sistem ini, udara lingkungan dipanaskan ketika melalui kondensor kemudian dilembabkan di humidifier (karena bercampur dengan semprotan air laut oleh sprinkler) dengan dorongan fan aksial (proses humidifikasi). Udara lembab ini didinginkan ketika melewati evaporator (dehumidifier), sehingga udara mengembun menjadi air tawar (proses dehumidifikasi). Air laut diberi pemanasan awal (preheating) sebelum disemprotkan menggunakan sprinkler ke humidifier untuk menambah kelembaban udara kering dari kondensor.

Parameter-parameter yang berhubungan dengan unit desalinasi ini adalah sebagai berikut; refrigeran yang digunakan pada unit pompa kalor adalah HFC 134a, dan kompresor yang digunakan adalah tipe torak 2 silinder. Kondensor yang digunakan berjumlah 2 buah dengan dimensi masing-masing kondensor $(\mathrm{cm}) 58 \times 36 \times 1,5$. Evaporator yang digunakan adalah tipe window 2 PK berjumlah 2 buah yang dipasang secara paralel. Humidifier yang digunakan terbuat dari aluminium dengan dimensi (cm) $30 \times 37 \times 35$. Sketsa struktur humidifier ditunjukkan pada gambar 2. Sprinkler pada penelitian ini berjumlah 5 buah yang dipasang di atas humidifier, disusun membentuk segiempat dengan jarak antar sprinkler $16,5 \mathrm{~cm}$. Untuk mengukur laju aliran volumetrik air laut digunakan sebuah rotameter, sedangkan untuk memanaskan air laut digunakan pemanas air listrik. Termokopel yang digunakan dalam penelitian ini adalah termokopel tipe $\mathrm{T}$ dengan diameter $0,1 \mathrm{~mm}$. Flowmeter refrigeran yang digunakan adalah Variable Area Glass Flowmeter Dwyer tipe VA 20440.9. Skema cara kerja spray humidifier untuk proses humidifikasi udara dapat dilihat pada gambar 3 .

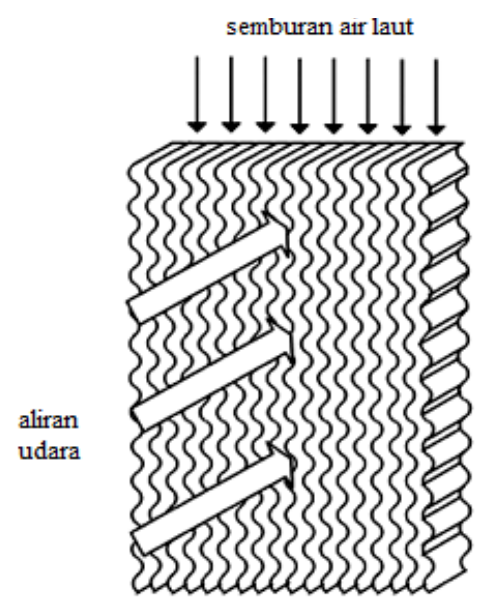

Gambar 3. Skema spray humidifier (Gao, 2008) 
Gambar spray humidifier dan pad humidifier yang digunakan dalam penelitian ini berturut-turut dapat dilihat pada gambar 4 dan 5. Spray humidifier yang digunakan terbuat dari plat aluminium dengan dimensi panjang $30 \mathrm{~cm}$, lebar $37 \mathrm{~cm}$, tinggi $35 \mathrm{~cm}$ yang disusun secara sejajar sebanyak 72 buah dengan jarak antar plat $5 \mathrm{~mm}$ dan sudut elevasi $45^{\circ}$ tiap gelombangnya. Pada spray humidifierterdapat 5 buah sprinkler untuk mengabutkan air laut menjadidropletdroplet, sehingga memperluas bidang kontak antara cairan air laut dengan udara. Udara akan terhumidifikasi ketika melewati spray humidifier.

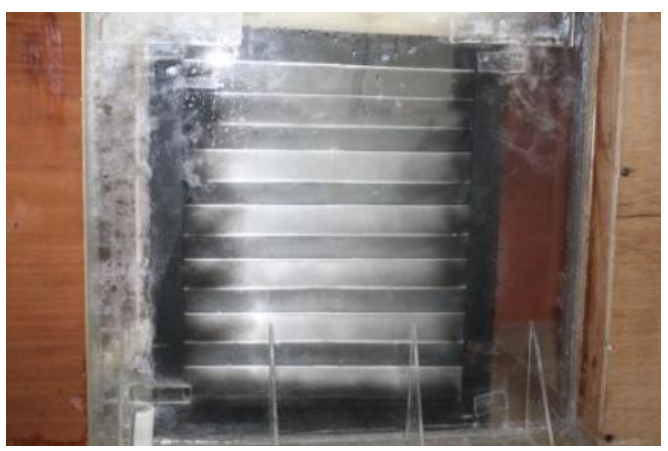

Gambar 4. Spray humidifier

Pad humidifier yang digunakan terbuat dari susunan karung goni yang mengandung bahan selulosa. Pad humidifier ini memiliki dimensi panjang $20 \mathrm{~cm}$, lebar $35 \mathrm{~cm}$ dan tinggi $35 \mathrm{~cm}$, dengan jumlah lembaran karung goni 55 lembar dan jarak susunan antar lembar $0,6 \mathrm{~cm}$. Pada pad humidifiertidak menggunakan sprinkler tetapi air laut didistribusikan dari atas secara merata dengan cara mengalirkan air laut melalui pipa yang telah dilubangi yang diletakkan di atas pad humidifierdengan tujuan pad humidifier dapat menyerap air laut secara maksimal. Dari arah bersilangan udara akan terhumidifikasi ketika melewati permukaan yang basah yakni di sela-sela dari pad humidifier.

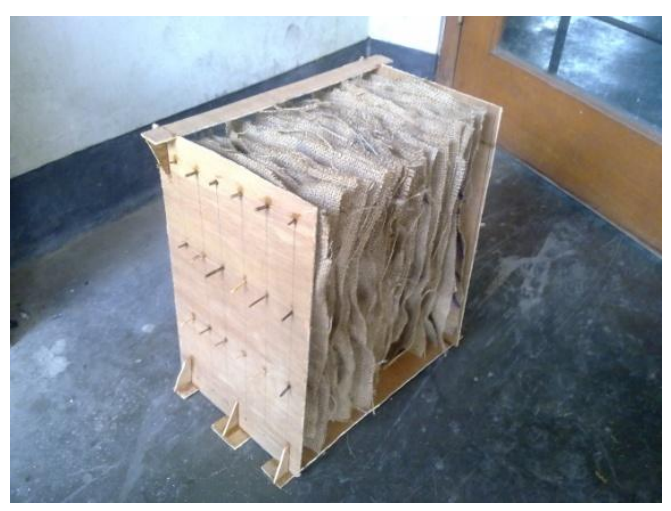

Gambar 5. Pad humidifier

Pengujian produktivitas unit desalinasi dengan menggunakan spray humidifier dan padhumidifier dilakukan dengan memvariasi debit air laut masuk humidifier, kecepatan udara masuk humidifier dan temperatur air laut masuk humidifier. Pengujian pengaruh debit air laut terhadap produksi air tawar dengan spray humidifier dan pad humidifier diuji pada debit 50 l/jam, 100 l/jam, 150 l/jam dan 200 1/jam, dimana temperatur air laut masuk humidifier sebesar $45^{\circ} \mathrm{C}$ dan kecepatan udara masuk humidifier 6 $\mathrm{m} / \mathrm{s}$. Pengujian pengaruh kecepatan udara masuk humidifierterhadap produksi air tawar dengan spray humidifier dan pad humidifier diuji pada kecepatan 3 $\mathrm{m} / \mathrm{s}, 4 \mathrm{~m} / \mathrm{s}, 5 \mathrm{~m} / \mathrm{s}$ dan $6 \mathrm{~m} / \mathrm{s}$, dimana temperatur air laut masuk humidifier sebesar $45^{\circ} \mathrm{C}$, dan debit air laut $100 \mathrm{l} / \mathrm{jam}$. Pengujian pengaruh temperatur air laut terhadap produksi air tawar dengan spray humidifier dan pad humidifier diuji pada temperatur $35^{\circ} \mathrm{C}, 45^{\circ} \mathrm{C}$, dan $55^{\circ} \mathrm{C}$, dimana kecepatan udara masuk humidifier sebesar $6 \mathrm{~m} / \mathrm{s}$, dan debit air laut 150 1/jam. Seluruh pengujian menggunakan air laut yang mempunyai salinitas $31.342 \mathrm{ppm}$, dan air laut dalam sistem ini disirkulasi ulang.

Data penelitian yang diambil adalah besar tekanan masuk dan keluar pada kompresor, kondensor, dan evaporator; temperatur refrigeran yang masuk dan keluar pada evaporator, temperatur refrigeran yang masuk dan keluar pada kondensor, temperatur udara sebelum dan sesudah humidifier, temperatur udara sebelum dan sesudah dehumidifier dan volume air tawar yang dihasilkan. Unit desalinasi dijalankan selama 180 menit untuk masing - masing variasi, dimana pengambilan data dilakukan setiap 20 menit.

Penambahan massa uap air total sesudah humidifier $\left(\Delta W_{l}\right)$ dalam $\mathrm{kg} / \mathrm{s}$, dapat dihitung dengan persamaan :

$$
\Delta W_{1} \quad=\dot{m}_{a 1}\left(w_{2}-w_{1}\right)(1)
$$

Pengurangan massa uap air total sesudah dehumidifier (evaporator) $\left(\Delta W_{2}\right)$ dalam $\mathrm{kg} / \mathrm{s}$ dapat dihitung dengan persamaan :

$\Delta W_{2}=\dot{m}_{a 2}\left(w_{2}-w_{3}\right)(2)$

dimana $\dot{m}_{a 1}$ dan $\dot{m}_{a 2}$ berturut-turut adalah laju aliran massa udara sebelum humidifier dan laju aliran massa udara sesudah humidifier atau sebelum dehumidifier $(\mathrm{kg} / \mathrm{s})$. Sedangkan $\mathrm{w}_{1}, \quad \mathrm{w}_{2}$ dan $\mathrm{w}_{3}$ berturut-turut adalah rasio kelembaban udara masuk humidifier, keluar humidifier dan keluar dehumidifier (kg uap air/kg udara kering).

\section{HASIL DAN PEMBAHASAN}

\section{Pengaruh Debit Air Laut Masuk Humidifier Terhadap Produksi Air Tawar}

Gambar 6 menunjukkan grafik produksi air tawar terhadap debit air laut yang diumpankan ke humidifier. Produksi air tawar adalah fungsi dari penambahan massa uap air totalsesudahhumidifier, pengurangan massa uap air totalsesudah dehumidifier dan debit air laut masuk humidifier.Pada gambar 6 terlihat bahwa semakin besar debit air laut yang diumpankan ke spray humidifier maupun pad humidifier, maka semakin besar produksi air tawar 
yang dihasilkan. Hal ini dikarenakan dengan semakin tinggi debit air laut, maka udara yang keluar dari humidifier juga semakin banyak membawa massa uap air sehingga semakin tinggi kelembaban udara setelah melewati humidifier. Hal ini mengakibatkan penambahan massa air total dalam udara setelah melewati humidifier juga semakin tinggi.

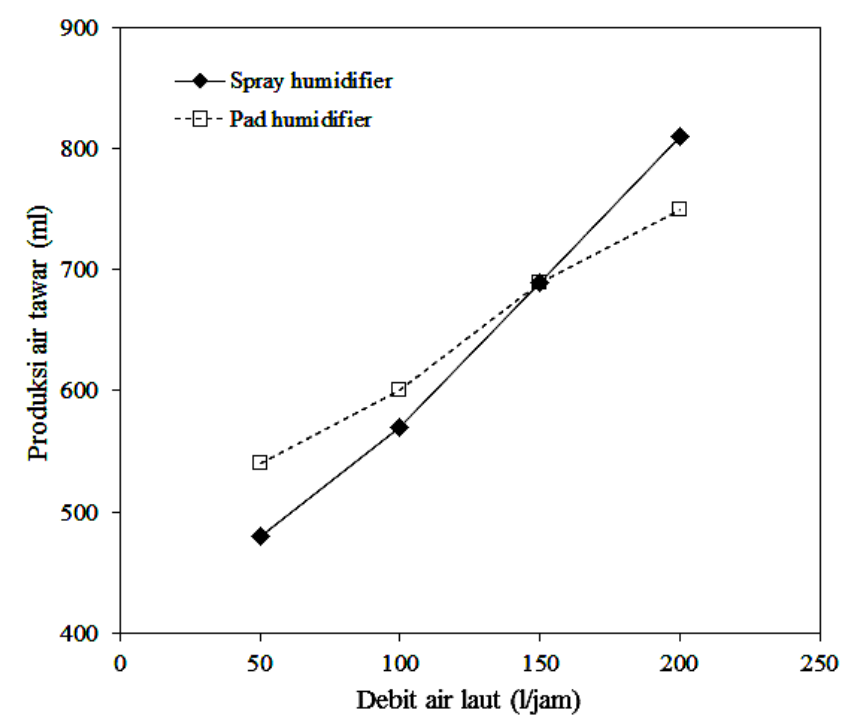

Gambar 6. Grafik produksi air tawar terhadap debit air laut

Pada gambar 6 terlihat bahwa spray humidifier dan pad humidifier menghasilkan produksi air tawar yang sama ketika debit air laut 150 1/jam atau ketika rasio laju aliran massa air laut terhadap laju aliran massa udara sebesar 1,34. Pada rasio laju aliran massa air laut terhadap laju aliran massa udara kurang dari 1,34, penggunaan pad humidifier dalam unit desalinasi memberikan hasil produksi air tawar lebih tinggi dibandingkan menggunakan spray humidifier. Sedangkan untuk rasio laju aliran massa air laut terhadap laju aliran massa udara lebih dari 1,34, penggunaan spray humidifier dalam unit desalinasi memberikan hasil produksi air tawar lebih tinggi dibandingkan menggunakan pad humidifier. Hal ini terjadi karena penambahan kadar uap air yang lebih tinggi ketika udara melewati spray humidifier, dengan bertambahnya debit air laut kecepatan air laut relatif terhadap kecepatan udarameningkat, sehingga kontak antara uap air dengan udara semakin tinggi akibatnya udara lebih terhumidifikasi.

\section{Pengaruh Kecepatan Udara Masuk Humidifier Terhadap Produksi Air Tawar}

Gambar 7 menunjukkan grafik produksi air tawar terhadap kecepatan udara yang diumpankan ke humidifier. Produksi air tawar sebagai adalah fungsi dari penambahan massa uap air totalsesudah humidifier, pengurangan massa uap air total sesudah dehumidifierdan laju aliran massa udara masuk humidifier.Pada gambar 7 terlihat bahwa semakin tinggi kecepatan udara yang diumpankan ke spray humidifier maupun pad humidifier, maka semakin tinggi produksi air tawar yang dihasilkan. Hal ini dikarenakan dengan semakin besar kecepatan udara, maka semakin besar laju aliran massa udara sehingga semakin banyak menyerap uap air di humidifier. Pada gambar 7 terlihat bahwa spray humidifier dan pad humidifier menghasilkan produksi air tawar yang sama ketika kecepatan udara $4 \mathrm{~m} / \mathrm{s}$, atau ketika rasio laju aliran massa air laut terhadap laju aliran massa udara sebesar 1,3 .

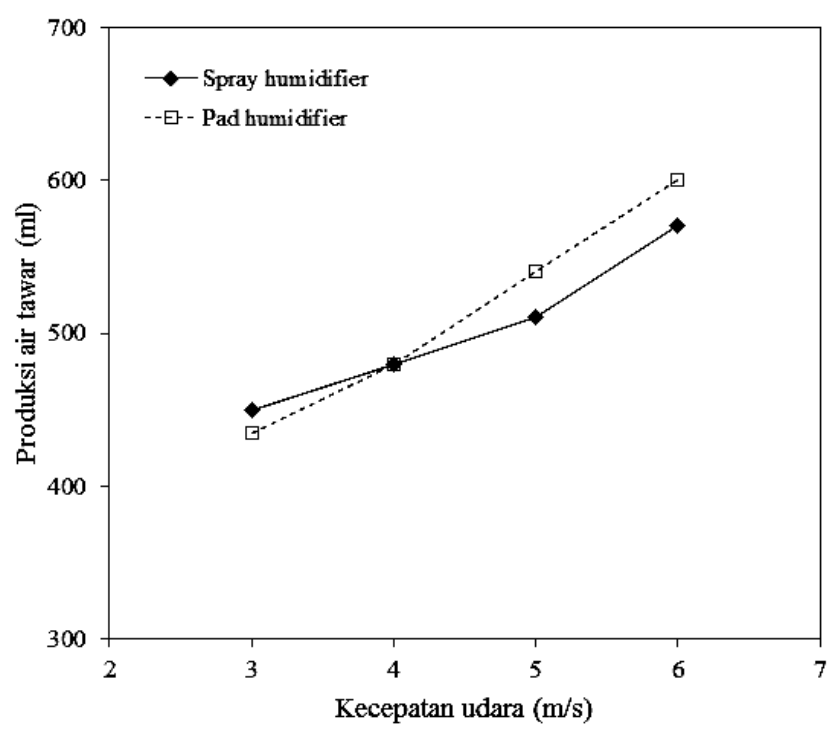

Gambar 7. Grafik produksi air tawar terhadap kecepatan udara

Pada rasio laju aliran massa air laut terhadap laju aliran massa udara kurang dari 1,3 penggunaan pad humidifier dalam unit desalinasi memberikan hasil produksi air tawar lebih tinggi dibandingkan menggunakan spray humidifier. Sedangkan untuk rasio laju aliran massa air laut terhadap laju aliran massa udara lebih tinggi dari 1,3, penggunaan pad humidifier dalam unit desalinasi memberikan hasil produksi air tawar lebih rendah dibandingkan menggunakan spray humidifier.

\section{Pengaruh Temperatur Air Laut Masuk Humidifier Terhadap Produksi Air Tawar}

Gambar 8 menunjukkan grafik produksi air tawar terhadap temperatur air laut yang diumpankan ke humidifier. Produksi air tawar adalah fungsi dari penambahan massa uap air totalsesudah humidifier, pengurangan massa uap air total sesudah dehumidifierdan temperatur air laut masuk humidifier.Pada gambar 8 terlihat bahwa semakin tinggi temperatur air laut yang diumpankan ke spray humidifier maupun pad humidifier, maka semakin besar produksi air tawar yang dihasilkan. Hal ini dikarenakan rasio kelembaban udara (w) dari temperatur air laut $35^{\circ} \mathrm{C}$ sampai $55^{\circ} \mathrm{C}$ semakin meningkat setelah melalui proses humidifikasi di dalam humidifier, sehingga kadar uap air yang dibawa udara untuk proses pengembunan semakin banyak. Dengan meningkatnya rasio kelembaban maka 
penambahan massa uap air total semakin tinggi pula, yang kemudian dikondensasi untuk menjadi air tawar juga semakin banyak.

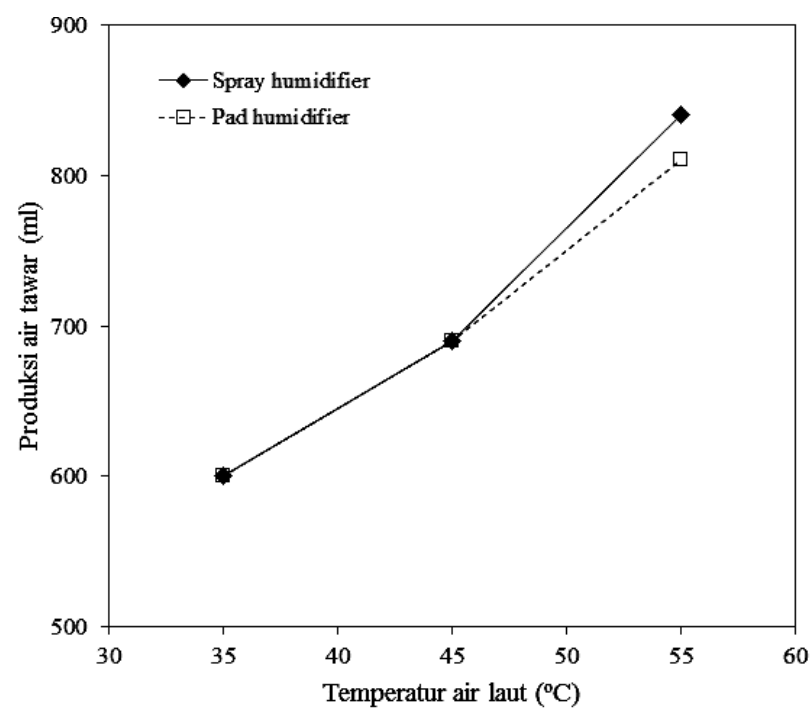

Gambar 8. Grafik produksi air tawar terhadap temperatur udara

Pada gambar 8terlihat bahwa spray humidifier dan pad humidifier menghasilkan produksi air tawar yang sama ketika temperatur air laut $35^{\circ} \mathrm{C}$ dan $45^{\circ} \mathrm{C}$ dengan rasio laju aliran massa air laut terhadap laju aliran massa udara sebesar 1,3. Spray humidifier memberikan hasil produksi air tawar yang sedikit lebih tinggi dibandingkan pad humidifier ketika temperatur air laut $55^{\circ} \mathrm{C}$, hal ini terjadi karena udara mengandung kadar kelembaban yang lebih tinggi setelah melewati spray humidifier dibandingkan kadar kelembaban udara setelah melewati pad humidifier.

\section{Pengaruh Penggunaan Spray dan Pad Humidifier Terhadap Salinitas Air Tawar}

Dari hasil pengujian salinitas air tawar diperoleh bahwa salinitas air tawar yang dihasilkan unit desalinasi dengan menggunakan pad humidifier adalah 140 ppm. Sedangkan salinitas air tawar yang dihasilkan unit desalinasi dengan menggunakan spray humidifier adalah $620 \mathrm{ppm}$. Hal ini dikarenakan pada pemakaian pad humidifier, konsentrat garam tertinggal dan tersaring pada lembaran dari pad humidifier, sehingga uap air yang terbawa oleh udara adalah mendekati uap air murni. Sedangkan pada pemakaian spray humidifier memberikan hasil salinitas air tawar yang lebih tinggi, hal ini dikarenakan udara ketika melewati dari spray humidifier selain membawa uap air juga ada sebagian droplet yang terbawa pada aliran udara.

\section{KESIMPULAN}

Produksi air tawar dari unit desalinasi berbasis pompa kalor dengan menggunakan proses humidifikasi dan dehumidifikasi meningkat seiring dengan meningkatnya debit air laut, kecepatan udara dan temperatur air laut masuk humidifier, ini berlaku pada penggunaanspray humidifier maupun pad humidifier dalam unit desalinasi. Pada pengujian pengaruh debit air laut, kecepatan udara dan temperatur air laut masuk humidifier, penggunaan spray humidifier dan pad humidifier dalam unit desalinasi menghasilkan produksi air tawar yang sama, ketika rasio laju aliran massa air laut terhadap laju aliran massa udara berturut-turut 1,34; 1,30; dan 1,30 .

\section{DAFTAR PUSTAKA}

[1] Sinha, R.K.,2010, Desalination\&Water Purification Technologies, Government of India, Mumbai.

[2] Cipollina, A, Micale, G, Rizzuti, L., 2009, Seawater Desalination-Conventional and Renewable Energy Processes, Springer-Verlag Berlin Heidelberg.

[3] Kalogirou, S.A., 2005, "Solar thermal collectors and applications", Progress in Energy and Combustion Science, Vol. 30, 231-295.

[4] Slesarenko, V.V., 2001, "Heat pumps as a source of heat energy for desalination of seawater", Desalination, Vol. 139, 405-410.

[5] Gao, P., Zhang, L., Zhang, H., 2008, "Performance analysis of a new type desalination unit of heat pump with humidification and dehumidification", Desalination, Vol. 220, 531-537

[6] Istanto, T., Juwana, W.E., Yaningsih, I., Hermawan, D., 2011, "The effect of feed seawater and air temperatures on performance of a desalination unit of heat pump with humidification and dehumidification", Proceeding of International Conference and Exhibition Sustainable Energy and Advanced Material, tanggal 3-4 Oktober 2011, Fakultas Teknik UNS

[7] Yaningsih, I., dan Istanto, T., 2014, "Studi eksperimental pengaruh laju aliran massa udara terhadap produktivitas air tawar unit desalinasi berbasis pompa kalor dengan menggunakan proses humidifikasi dan dehumidifikasi", Prosiding Seminar Nasional Sains dan Teknologi ke-5 Tahun 2014 (SNST ke-5 Tahun 2014), tanggal 25 Juni 2014, Fakultas Teknik Universitas Wachid Hasyim Semarang

[8] Yaningsih, I., dan Istanto, T., 2014, "Pengaruh laju aliran massa air laut terhadap produktivitas unit desalinasi berbasis pompa kalor dengan Prosiding Seminar Teknoin 2014, tanggal 22 November 2014, Fakultas Teknologi Industri Universitas Islam Indonesia Yogyakarta

[9] Yaningsih, I., Istanto, T., Juwana, E.J., 2014, "Pengaruh kecepatan putaran kompresor terhadap produktivitas unit desalinasi berbasis pompa kalor dengan proses humidifikasi dan dehumidifikasi”, Jurnal Mechanical, Vol. 5, 2328 
[10] Yanniotis, S., Xerodemas. K., 2003, "Air humidification for seawater desalination", Desalination, Vol. 158, 313-319

[11] Amara, M.B., Houcine,I., Guizani, A., Maalej, M., 2004, "Theoretical and experimental study of a pad humidifier used in a seawater desalination process", Desalination, Vol. 168, $1-12$.

[12] Amer, E.H., Kotb, H., Mostafa, G.H., El Ghalban, A.R., 2009, "Theoritical and experimental investigation of humidification dehumidification desalination unit", Desalination, $\quad$ Vol. 249, 949-959 